Rozprawy Komisji Językowej ŁTN, t. LXVII, 2019

ISSN 0076-0390; e-ISSN 2450-9310

https://doi.org/10.26485/RKJ/2019/67/1

Irena Bogoczová*

(D) https://orcid.org/0000-0002-0818-193X

\title{
MOWA POLAKÓW NA ZAOLZIU (W KONTEKŚCIE JĘZYKÓW OGÓLNONARODOWYCH I ICH ODMIAN)
}

\author{
THE SPEECH OF POLES IN THE ZAOLZIE REGION (IN THE CONTEXT \\ OF ETHNIC LANGUAGES AND THEIR VARIETIES)
}

Contemporary common language and traditional dialect are not the same in the Czech Part of Cieszyn in Silesia. The dialect has its own standard, while common speech is a mixed, open system, especially at a lexical level, and unlike the traditional dialect is able to express the sense of necessary things. Keywords: Czech part of Cieszyn in Silesia, Polish language, Czech language, dialect, mixed language

Słowa kluczowe: czeski Śląsk Cieszyński, język polski, język czeski, gwara, język mieszany

\section{PRÓBA DEFINICJI POJĘĆ}

Zanim rozpoczniemy omawianie tematów lingwistycznych i socjolingwistycznych związanych z sytuacją językową na Zaolziu, musimy, choćby w skrócie, wyjaśnić znaczenie samego pojęcia Zaolzie i jego derywatów, jak np. Zaolzianin/ Zaolzianie czy (wspólnota, etniczność, subkultura, gwara) zaolziańska.

Należy zaznaczyć, że z omawianym tematem wiąże się wiele nazw geograficzno-politycznych: Śląsk Cieszyński, Księstwo Cieszyńskie, Śląsk Austriacki, Komora Cieszyńska, Gubernium Morawsko-Śląskie, czeski Śląsk Cieszyński, polski Śląsk Cieszyński i inne, nie wspominając o ekwiwalentnych nazwach czeskich lub niemieckich.

* Uniwersytet Ostrawski, Wydział Filozoficzny, Katedra Slawistyki, ul. Reální 5, 70103 Ostrawa 1; e-mail: irena.bogoczova@osu.cz. 
Początków formowania się tego regionu upatrywać można w czasach piastowskich, gdy Śląsk Cieszyński został wydzielony z Księstwa Opolskiego (1290 r.). Komora Cieszyńska (Teschner Kammer) to już okres panowania Habsburgów, zapoczątkowany po śmierci ostatniej cieszyńskiej Piastówny Elżbiety Lukrecji (1653 r.). W granicach tej jednostki znalazły się stopniowo odkupywane i zagospodarowywane podupadłe majątki byłych książąt pochodzących z cieszyńskiej linii Piastów, tworząc mniej lub bardziej jednolitą całość. W czasach istnienia Komory Cieszyńskiej, a szczególnie Gubernium Morawsko-Śląskiego z siedzibą w Brnie (1783-1849), do którego została włączona ziemia cieszyńska, nasiliła się germanizacja, przejawiająca się w znacznym stopniu nawet po podziale Gubernium na część morawską (z siedzibą w Brnie) i śląską (z siedzibą w Opawie).

Od czasów habsburskich aż do końca I wojny światowej Śląsk Cieszyński był więc częścią Śląska Austriackiego. Powierzchnia Śląska Cieszyńskiego przed jego podziałem wynosiła $2282 \mathrm{~km}^{2}$. W 1920 roku, po dwuletnim okresie rywalizacji sąsiadujących ze sobą młodych państw - czechosłowackiego i polskiego, doszło - na podstawie decyzji podjętej przez Radę Ambasadorów w belgijskim mieście Spa - do rozpadu tego terytorium (a nawet do podziału samego Cieszyna) na dwie części: Czechosłowacji przypadło $1280 \mathrm{~km}^{2}$, Polsce $1002 \mathrm{~km}^{2}$. Termin Zaolzie jest więc na tle dziejów tego regionu pojęciem względnie młodym ${ }^{1}$, odnoszącym się do terenów znajdujących się z perspektywy Polski na przeciwległym (lewym) brzegu granicznej² rzeki Olzy, czyli ,za Olzą”. Termin ten nie obejmuje jednak całej czeskiej powierzchni Śląska Cieszyńskiego, a tylko tę, która w październiku 1938 roku, w trudnym dla narodu czeskiego okresie przedmonachijskim, została na niespełna rok przyłączona do Polski (około $805 \mathrm{~km}^{2}$ ). Pozostała, bardziej odległa od Olzy część czeskiego Śląska Cieszyńskiego (około 480 km²), należała jednak nadal do Czechosłowacji. Przez sześć kolejnych lat Zaolzie mieściło się w granicach Rzeszy Niemieckiej, a po wyzwoleniu zostały przywrócone jego granice sprzed 1938 roku. Od podziału państwa czechosłowackiego na czeskie i słowackie (31 grudnia 1992 r.) Zaolzie mieści się w granicach Republiki Czeskiej.

Drugim zasygnalizowanym pojęciem wymagającym wyjaśnienia jest $Z a$ olzianin, którego nie utożsamiamy z obywatelem Zaolzia, ponieważ nie każdy

1 Na opisywanych obszarach istniała i nadal istnieje podobna nazwa terenowa, konkretnie w miejscowości Wędrynia (Vendryně), leżącej po obu brzegach rzeki Olzy. Lewobrzeżną dzielnicę tej gminy określa się gwarowo jako Zaolzi albo Zoolzi, po czesku oficjalnie Vendryně-Zaolší.

2 Mająca prawie $100 \mathrm{~km}$ długości Olza odgrywa rolę rzeki granicznej tylko w pewnych odcinkach swojego biegu (łącznie ponad $25 \mathrm{~km}$ ): tuż przed Cieszynem, w samym mieście, następnie na terenach w kierunku Karwiny oraz na północny zachód od Karwiny, w Boguminie - gdzie wpływa do Odry. Ma jednak ważną funkcję symboliczną. 
mieszkaniec tego regionu należy do tej kategorii. Trzeba stwierdzić, że Zaolzianin (potocznie Zaolziak):

1) jest autochtonem; urodził się i mieszka w czeskiej części Śląska Cieszyńskiego (przed rokiem 1918 urodził się w Austrii, w okresie od października 1938 do września 1939 roku - w Polsce, w latach 1939-1945 - w Rzeszy Niemieckiej) i sam nigdzie się nie przenosił (zmieniały się tylko granice);

2) należy do mniejszości polskiej w Republice Czeskiej, deklaruje narodowość polską (równocześnie ma czeskie obywatelstwo) lub na temat narodowości nie wyraża się w sposób jednoznaczny, na przykład ze względu na pochodzenie z małżeństwa mieszanego;

3) nierzadko angażuje się proetnicznie, tworzy specyficzną subkulturę lokalną, jest zrzeszony w którejś z organizacji mniejszościowych (jest członkiem Polskiego Związku Kulturalno-Oświatowego, występuje w zespole folklorystycznym, śpiewa w chórze itp.), a jeżeli nawet nie bierze aktywnego udziału w tworzeniu lokalnej polskiej subkultury zaolziańskiej, to jednak w chwilach decydujących staje po stronie polskości;

4) w pewnym sensie identyfikuje się kulturowo (w tym także językowo) i moralnie (emocjonalnie) z resztą narodu polskiego (czego nie czyni członek czeskiej wspólnoty większościowej); o wiele głębsze emocje odczuwa w stosunku do polskiej zbiorowości lokalnej, jednak na co dzień bardziej obchodzi go to, co dzieje się w państwie czeskim, gdzie się kształci, zarabia, oszczędza i wydaje pieniądze, korzysta ze służby zdrowia, świadczeń społecznych itd.;

5) skończył mniejszościową szkołę podstawową (ewentualnie też liceum) z polskim językiem nauczania (najstarsza generacja Zaolzian mogła jeszcze uczęszczać do szkół niemieckojęzycznych); własne dzieci zapisał do polskiej szkoły, ewentualnie do szkoły czeskiej;

6) język polski w jego kulturalnej odmianie ogólnej zna przynajmniej pasywnie - w formie pisanej i mówionej, ponieważ zdobył w tym języku wykształcenie (co najmniej podstawowe); od drugiej klasy szkoły podstawowej uczył się równocześnie języka czeskiego w takim samym wymiarze godzinowym i na takim samym poziomie jak uczniowie szkół większościowych; język czeski zna też z mediów i innych źródeł, nieraz z komunikacji we własnej rodzinie, częściej

3 Wiele słusznych uwag na temat podawania narodowości (tożsamości etnicznej), jej mierzalności lub stopniowalności, jej obiektywnego uzasadnienia itp. można znaleźć w pracy Naród - Tożsamość - Kultura. Między koniecznościa a wyborem [Burszta, Jaskułowski, Nowak, 2005]. W źródle rozważa się między innymi narracyjny charakter tego bytu, chodzi bowiem o świadomość, która nie odzwierciedla rzeczywistości, ale jest odniesieniem umysłu człowieka do niej [Misztal, 2005, s. 24]. 
jednak ze środowiska pozaszkolnego, z komunikacji koleżeńsko-sąsiedzkiej, z miejsca pracy, dawniej z wojska itp.;

7) w domu (rodzinie) lub w codziennych kontaktach nieformalnych na terenie Zaolzia używa mowy „po naszymu”, którą często nazywa gwarą; ten warunek spełniają jednak również osoby deklarujące narodowość czeską, miejscowi Czesi, szczególnie generacja najstarsza lub średnia, więc mówienie „po naszymu” nie jest rozstrzygającym wyznacznikiem etniczności [por. Bogoczová, Bortliczek, 2016].

Poza społecznością zaolziańską istnieje wspomniana już lokalna i ogólnopaństwowa społeczność większościowa (czeska) oraz Polacy w Polsce. Nie wdając się w charakterystykę poszczególnych punktów widzenia (zaolziańskiego, czeskiego, polskiego), różniących się od siebie w zależności od tego, kto jest przedmiotem, a kto podmiotem oceny, pragniemy zasygnalizować istnienie kilku istotnych kategorii. Sam Zaolzianin, oprócz podziału członków własnej zbiorowości, czyli pozostałych Zaolzian, zgodnie z trzecim punktem omawianych powyżej cech zaolziańskiej etniczności dostrzega różnicę między Zaolzianinem „zażranym”, tzn. 'zażartym, zagorzałym zwolennikiem polskości Zaolzia', a ambiwalentnym. W ramach lokalnej grupy większościowej odróżnia się Czecha napływowego od Czecha-autochtona, często o zdecydowanie polskich korzeniach i polskim nazwisku, czyli tzw. szkopyrtoka ${ }^{4}$.

\section{JEZZYKOWE (GWAROWE, SOCJOLEKTALNE) TLO MOWY ZAOLZIAN}

Na mowę Zaolzian wywarły i nadal wywierają wpływ dwa języki zachodniosłowiańskie - polski i czeski, a na samym wschodzie także gwary czadeckie - zaliczane do obszaru słowackiego języka etnicznego, ale wykazujące wiele małopolskich cech gwarowych. Istotnym kodem był w przeszłości również język niemiecki, używany też w ramach lokalnej wspólnoty żydowskiej. W toponimii można też zauważyć obecność nazw, które odnoszą się do kolonizacji wołoskiej.

Język polski w swojej odmianie kulturalnej - ogólnej (nazywany tu nadal polszczyzną literacką) jest przede wszystkim językiem szkolnym. Godząc się z twierdzeniem, że Zaolzianie są dwujęzyczni, pamiętajmy o tym, że chodzi o bilingwizm asymetryczny, „uwarunkowany edukacyjnie”, uprawiany świadomie i celowo [Lipińska, 2015, s. 55], że znajomość ogólnego języka polskiego

4 Wyraz szkopyrtok został utworzony od czasownika szkopyrtnyć/szkopyrtnóć (po czesku (za)škobrtnout), co oznacza "potknąć się'. Odnosi się do człowieka, który „potyka się/potknął się" moralnie, światopoglądowo, przy okazji zmian politycznych lub ustrojowych, zapominając o tym, do której grupy społecznej właściwie należy/należał. W ten sposób określa się zwykle kogoś, kto zmienił narodowość (z polskiej na czeska). 
w wypadku Zaolzian nie dorównuje poziomowi kompetencji użytkowników polszczyzny w Polsce. Pod tym względem lokalny język polski można przyrównać do polszczyzny polonijnej. Rozwój tego kodu jest opóźniony, czego wynikiem jest jego archaiczny, skostniały charakter. Między nim a pozostałymi językami i ich odmianami zachodzi interferencja. W wymowie łatwo dostrzec przede wszystkim elementy gwarowe, rzadziej czeskie (np. w nazwach własnych obcego pochodzenia: vanylka, pica, rizoto i innych), wyraźnie słyszy się na przykład różnicę między frykatywnym $\check{r}$ (dźwięcznym i bezdźwięcznym) a ž/šs, między $h$ i ch itd. W morfologii, zarówno słowotwórczej, jak i fleksyjnej, pojawiają się tendencje typowe dla języka czeskiego (uwzględnianie różnicy żywotność/ nieżywotność, włączanie wyrazów obcych, np. na -um: muzeum, gimnazjum, stadium itp., do słowiańskiego systemu fleksyjnego, preferencja stopniowania prostego, zdecydowana przewaga derywacji nad zapożyczaniem itd.). Wpływ języka czeskiego najbardziej jednak przejawia się w leksyce i frazeologii oraz w składni i w sferze pragmalingwistycznej (np. czeskie formy grzecznościowe). Szczególnie wyraźny jest udział słownictwa czeskiego w potocznej odmianie języka polskiego, wypadałoby napisać: w kodzie projektowanym jako potoczna polszczyzna, ponieważ polskie wyrazy nieliterackie (łącznie z socjolektyzmami) są Zaolzianom raczej nieznane. Powtarzamy za gronem innych badaczy sytuacji językowej na Zaolziu [np. Kadłubiec, 1994, s. 37], że regionalna potoczna odmiana języka polskiego nigdy się tutaj nie wykreowała. Jej rolę pełniły inne odmiany języka: gwara (zachodnio)cieszyńska lub mowa „po naszymu” (patrz dalej), w których dawniej więcej było germanizmów, natomiast dziś więcej jest bohemizmów leksykalnych. Doświadczenie Zaolzian z potoczną polszczyzną jest więc znikome, dlatego swobodna, spontaniczna rozmowa z Polakami z Polski przysparza im znacznych trudności. Język polski w odmianie literackiej widnieje na dwujęzycznych napisach w miejscach publicznych (nazwy miejscowości, ulic/ placów, stacji kolejowych, instytucji, rzadziej sklepów itp.).

Język czeski w „wykonaniu” Zaolzian jest taki sam lub prawie taki sam jak język czeski innych mieszkańców terenów śląskich/laskich. Pojawiają się w nim usterki, jak na przykład niedotrzymywanie różnicy między samogłoskami krótkimi i długimi (na korzyść krótkich), czasami paroksytoniczny akcent, niepoprawna w języku czeskim progresywna asymilacja dźwięczności [sfuj], [tfuj], [kfitko] zamiast [svu:j], [tvu:j], [kvjet'ina], niektóre błędy gramatyczne wynikające z odmienności kategorii rodzaju lub przypadka, z innej kolokacji, rekcji czasownikowej, przyimkowej itp. Nieformalne porozumiewanie się Zaolzian (szczególnie najmłodszej generacji) z Czechami przebiega mimo wszystko bezproblemowo. 
Tradycyjna gwara (zachodnio)cieszyńska jest obecnie odmianą zamknięta, zastygłą w kręgu folkloru narracyjnego lub sporadycznie uprawianej literackiej twórczości gwarowej. Zawiera wiele wyrazów niemieckich, które zostały poddane presji gwarowego systemu fonologicznego oraz gramatycznego (fleksji). Należy podkreślić, że leksemy czeskie występują także w tradycyjnej gwarze cieszyńskiej (np. cesta 'droga', koło 'rower', źivać śe 'patrzeć' i inne). Wspomniana powyżej gwarowa twórczość ludowa, szczególnie ta uprawiana w sposób amatorski (np. humorystyczne teksty do gazet lokalnych, słowa piosenek pewnej popularnej grupy wokalno-instrumentalnej), zdradza wyraźne cechy „czeskiego” oglądania rzeczywistości pozajęzykowej, „czeskiego” sposobu myślenia, „czeskiego" językowego obrazu świata.

Czwartą kategorią mowy jest przywołana już niejednokrotnie mowa „po naszymu", czyli domowa, tutejsza, swojska, bliska, prosta... Jest wypadkową wcześniej omówionych języków i ich odmian, jest - posługując się terminami innych językoznawców - ich mieszanina, mieszanką, melanżem, konglomeratem, konwergentem itd., a kto wie, czy nawet nie pewnego rodzaju pidżynem ${ }^{5}$ powstałym na podłożu gwarowym i stanowiącym być może jedyne wyjście z całego tego językowego i gwarowego impasu. Mowa „po naszymu” jest dynamiczna, nieuchwytna, w pewnym sensie promiskuitywna, zmienna, tak jak zmienna jest rzeczywistość, którą opisuje [Bogocz, 2017a]. Nie ma normy, może przyjmować postać bardziej polską lub bardziej czeską [Labocha, 1997, s. 129], wykazuje cechy ogólnego języka mówionego, tworów systemowo zmodyfikowanych, zmierzających w kierunku „neogwar”, zaspokajających - jak określił to Bogusław Nowowiejski - „specjalne potrzeby komunikatywne” ich użytkowników, wyzbywających się jednocześnie „balastu przeszłości” [Nowowiejski, 2010, s. 121-122]. Wbrew pozorom mowy tej w środowisku Zaolzia nikt się nie wstydzi. Nie przykleja się mówiącemu etykiety osoby zacofanej, niewykształconej, niesocjalizowanej, wsiowej, sędziwej itp. Korzystają z niej zarówno starsi mieszkańcy, jak i najmłodsza generacja Zaolzian. Używanie polszczyzny ogólnej zostałoby w nieformalnej komunikacji odebrane jako chęć bycia kimś, kim się nie jest, stwarzania dystansu wobec współrozmówcy itp. Mowa „po naszymu” nie jest kodem gwarowym, ale kodem stosownym do sytuacji gwarowej, gwarowym sposobem mówienia. Jej domeną są wszystkie potoczne gatunki konwersacji, łącznie z pisaną (np. za pośrednictwem sieci internetowej). Dowodem na to są

5 Tym, co nie pozwala w pełni traktować omawianego kodu mieszanego jako spidżynizowanego, jest na przykład komunikacja wychodząca poza sferę handlu i usług, symetryczny charakter rozwoju cywilizacyjnego obu wspólnot językowych, fakt, że dla żadnej z nich „pidżyn” ten nie jest językiem ojczystym [więcej: Bogoczová, 2015]. 
poniższe fragmenty dyskusji przebiegającej na Facebooku. Teksty podajemy $\mathrm{w}$ formie oryginalnej, nie czyniąc poprawek graficznych, ortograficznych, gramatycznych ani stylistycznych ${ }^{6}$.

gdyby gdosik miol nawiyncyj listek na colours tak bych miol zajem

kdyby měl někdo lístek na Colours (of Ostrava) navíc, tak bych měl zájem

gdyby ktoś miał wolny bilet na Colours, jestem zainteresowany

aspon se czlowiek pousmieje nad stupiditom nikierych otazek

aspoň se člověk pousměje nad stupiditou některých otázek

przynajmniej można się pośmiać z głupoty niektórych pytań

jakto, ze na tej predposledni fotce som moje 3D bryle ktore se mi zahadnie straciły a ktore postradóm, hmmm!?

jak to, že na té předposlední fotce jsou moje 3D brýle, které se mi záhadně ztratily a které postrádám, hm?

jak to się stało/jak to możliwe, że na tym przedostatnim zdjęciu są moje okulary 3D, które w tajemniczy sposób ,zgubiłem” i których mi brak, hm?

inaczy gratulujym ku swatbie;-) (przedpokladom ze byla uspieszno)

jinak, gratuluji/blahopřeji ke stvatbě (předpokládám, že byla úspěšná)

na marginesie/przy okazji gratuluję z okazji ślubu/wesela (zakładam, że się udał/udało)

Warto też przytoczyć kilka urywków wypowiedzi nagranych na dyktafon podczas rozmów z informatorami ${ }^{7}$ :

Jo był f Turecku, f pjyňćihvjeź̧ičkovym hotelu, ale mamje a tatovi było špatňe z jakśigo jezyn̆o...

Já jsem byl v Turecku, v pětihvězdičkovém hotelu, ale mámě a tátovi bylo špatně z nějakého jídla...

Byłem w Turcji, w pięciogwiazdkowym hotelu, ale mamie i tacie było niedobrze z jakiegoś pokarmu...

Jo by chćoł być zymbjoř, ale přijimački na tyn obor sûm strašňe ćynški...

Chtěl bych být zubař, ale přijímačky na tento obor jsou strašně těžké...

Chciałbym zostać dentystą, ale egzaminy na ten kierunek są bardzo trudne...

Jo třeba je $\mathrm{z} \_$Olbrachćic a to je vedle Havjyřova hnet a to je ganc inšy jynzyk, jo taki słova vubec ňepołžyvûm...

Já jsem třeba z Albrechtic a to je hned vedle Havírova, ale je to úplně jiný jazyk, já taková slova vůbec nepoužívám...

Ja na przykład jestem z Olbrachcic, które są koło Hawierzowa, ale język mamy tu zupełnie inny, takich słów w ogóle nie używam...

${ }^{6}$ Autorzy często rezygnują z interpunkcji, nie stosują czeskiej diakrytyki lub polskich dwuznaków dla oddania jednej głoski, nie poprawiają literówek itp. Pierwszy wiersz przykładu to oryginał, drugi i trzeci jest tłumaczeniem na język czeski i polski.

7 Fragmenty te pochodzą z monografii Język przygranicznego mikroświata... [Bogoczová, Bortliczek, 2014, 2017], a zostały zapisane fonetycznie, zgodnie z przyjętymi w monografii zasadami. 
Ałtobus jechoł přimo, ale tym cugym to je dali...

Autobus jel přímo, ale tím vlakem je to dál...

Jechał bezpośredni autobus, ale pociagiem było dalej...

Jo spiš teraz uš na počitaču se źivûm na filmy se třeba jakśi pośćûngûm, po angjelsku s titulkami...

Já se spíš ted' dívám na počítači na filmy, nějaké si třeba postahuji, v angličtině s titulky... Ja już teraz raczej na komputerze oglądam filmy, ściaggam jakieś po angielsku z napisami...

Do Polski na studja bedym skušać každopadňe...

Do Polska na vysokou (školu) to budu zkoušet každopádně...

W każdym razie będę próbował (dostać się) na studia w Polsce...

\section{PRZYNALEŻNOŚĆ JĘZYKOWA ZAOLZIA}

Zaolzie to obszar, na którym kontaktują się dwa języki etniczne, dokładniej - odmiany genetycznie polskie (południowośląskie) z gwarami laskimi, określanymi przez polskich językoznawców jako przejściowe (polsko-czeskie). Z czeskich dialektologów takie rozumienie sytuacji językowej na Zaolziu prezentował na przykład Bohuslav Havránek, którego opis narzeczy czeskich, przedstawiony w obszernym rozdziale publikacji Československá vlastivéda, tom III - Jazyk [Havránek, 1934], kończy się w strefie wyznaczonej przez miejscowości: Łomna Górna, Rzeka, Ligotka Kameralna, Dobracice, Domasłowice, Błędowice Dolne, Datynie Dolne, Szumbark, Pietwałd, Rychwałd, Pudłów czy Bogumin. To, co znajdowało się (znajduje się) po wschodniej stronie podanej linii, nie było przedmiotem uwagi ówczesnej czeskiej dialektologii. Autorzy prac pochodzących z okresu po II wojnie światowej przyjęli jednak inny punkt widzenia. Przyczyną tej zmiany była tendencja czeskiego językoznawstwa do uzasadnienia przynależności niektórych terenów geograficznych do przestrzeni czeskiego języka etnicznego. Dotyczyło to nie tylko Śląska Cieszyńskiego, ale też wschodnich części Moraw (pogranicza morawsko-słowackiego ${ }^{8}$ ) lub ziem, z których została wysiedlona ludność niemiecka [Bogoczová, 2017; Bogocz, 2017b]. Pod kątem ówczesnej ideologii (polityki językowej) zaczęły się zmieniać nie tylko dialektologiczne mapy Czechosłowacji, ale również używana dotychczas terminologia9 9

8 Jaromír Bělič, chyba najbardziej ceniony powojenny czeski dialektolog, w pracy Sedm Kapitol o češtině... z 1955 roku zmianę gwar zachodniosłowackich na wschodniomorawskie uzasadnił tym, że liczy się nie system języka (odmiany gwarowej), ale to, kim się czuje jego użytkownik i którą odmianę kulturalną uważa za ojczystą [Bělič, 1955].

9 Dla uzupełnienia należy dodać, że co najmniej od końca II wojny światowej ustalił się podział czeskiego języka etnicznego na cztery podstawowe zespoły dialektalne: 1) czeski sensu stricto (czeski właściwy, tzn. obejmujący zachodnie tereny języka czeskiego aż po Wyżynę Czesko-Morawską; w terminologii czeskiej: nářečni skupina česká v užším smyslu), 2) środkowomorawski 
W interesującej nas czeskiej części Śląska czescy badacze rozróżniają dialekty:

1) środkowolaski (centralny, ostrawski, středolašské nářeči),

2) zachodniolaski (opawski, západolašské nářeči) i

3) „morawski”, południowy (występujący w okolicach Štramberka lub Frenštátu, štrambersko-frenštátské nárečí, moravská podskupina lašských nářeči).

Za sprawą Adolfa Kellnera, a dokładnie jego dwutomowej publikacji zatytułowanej Východolašská nářeči [1946, 1947], został wprowadzony w obieg nowy termin - narzecza wschodniolaskie ${ }^{10}$, które - zdaniem autora - tworzą kolejny podzespół dialektów laskich. Obszar ich występowania utożsamił więc Kellner z przestrzenią gwary zachodniocieszyńskiej. Zinterpretował on te dialekty jako „typowo przejściowe”, podając w wątpliwość ich genetycznie polski charakter, a w słownictwie dostrzegał nawet przewagę elementów czeskich. Jego stanowisko wywołało sprzeciw zarówno ze strony polskich dialektologów (szczególnie Karola Dejny), jak również samych użytkowników omawianego subdialektu-Zaolzian, i zapoczątkowało burzliwą dyskusję, której przebieg został dokładnie przedstawiony w innej pracy [Bogocz, 2017b].

\section{WNIOSKI KOŃCOWE}

Reasumując, należy stwierdzić, że język polski na Zaolziu jest językiem symbolicznym, szkolnym, w codziennej komunikacji raczej nieprzydatnym. Język czeski nie różni się w sposób istotny od czeszczyzny innych części regionu śląskiego w Republice Czeskiej. Stopień jego opanowania zależy co prawda od indywidualnych zdolności mówiącego, ale ogólnie jego jakość w wypadku osób polskiej czy czeskiej narodowości jest porównywalna. Język niemiecki na opisywanych terenach już się nie rozwija, jego ślady są widoczne w terminologii specjalistycznej - hutniczej i górniczej, ale także potocznej (dotyczącej np. prowadzenia gospodarstwa domowego). Gwara zachodniocieszyńska, którą dawniej posługiwali się mieszkańcy czeskiego Śląska Cieszyńskiego o polskiej i czeskiej orientacji narodowej, została w ostatnich dziesięcioleciach zepchnięta na margines kompetencji językowej tutejszych Polaków.

Mowy „po naszymu” nie utożsamiamy z tradycyjną gwarą zachodniocieszyńską, choć zauważamy tu pewne socjo- lub pragmalingwistyczne zbieżności. Do

(nářeční skupina středomoravská), 3) wschodniomorawski (nářeční skupina východomoravská) oraz 4) laski (nářeční skupina slezská albo lašská).

${ }^{10}$ Jaromír Bělič, autor obszernej monografii dialektologicznej, wprowadził określenie nářeči polsko-českého smišeného pruhu [Bělič, 1972]. 
takich należy manifestacja zasiedziałości, przywiązania do regionu, spontaniczność, nieformalność, szczerość rozmowy. Odmienność polega zaś na tym, że nie da się opisać jej systemu, nie można podać jej normy, ułożyć i zaprezentować jej leksyki na przykład w słowniku itp.

Użytkownikiem odmiany języka zwanej „po naszymu” może być każdy członek miejscowej wspólnoty, który ją zna i chce z niej korzystać. „Po naszymu" mówi ten, kto ma odpowiednie kompetencje językowe (z reguły zna język czeski i w znacznej mierze język polski lub przynajmniej gwarę cieszyńską), nie ukrywa swoich polskich korzeni, nie unika kodu nieliterackiego, umyślnie nie stylizuje swojej wypowiedzi w danej sytuacji komunikacyjnej, używając jednego czy drugiego języka standardowego - czeskiego lub polskiego. „Po naszymu" komunikuje się ten, kto ma przyzwolenie środowiska zawodowego lub innoetnicznego partnera (męża/żony) itp. Czynniki typu stopień wykształcenia, pochodzenie społeczne, miejsce zamieszkania (w sensie miasto/wieś), sytuacja ekonomiczna nie mają tu żadnego znaczenia. Mowa „po naszymu” to po prostu środek codziennej potoczności, wspólna miejscowa antynorma. Utożsamianie jej niższym poziomem intelektualnym lub ograniczoną kompetencją językową jej użytkownika byłoby błędem.

Dla Zaolzian „po naszymu” to kod, który - jak określił to Jerzy Damrosz [1999, s. 29] - jest częścią składową etnotypu (zbioru w miarę trwałych cech zapewniających spójność danej grupy etnicznej), podczas gdy oficjalna, szkolna czeszczyzna lub polszczyzna pełni funkcję dysfunktora (zbioru zmiennych powodujących jej zróżnicowanie).

Wcześniejsze, tzn. powojenne, ekstremalnie odmienne stanowiska czeskich i polskich dialektologów na temat afiliacji gwary zaolziańskiej (zachodniocieszyńskiej) zostały z upływem lat częściowo zniwelowane. Czescy dialektolodzy skłonni są ponownie akceptować systemowo raczej polski charakter tego narzecza, stosując na przykład termin náreči slezskopolská.

Pisząc o Zaolziu, musimy pozbyć się ludycznego (folklorystycznego) wyobrażenia o tym regionie. Wizerunek tego terenu już od dawna nie opiera się wyłącznie na subkulturze ludowej, rolnictwie, pasterstwie itp. Wręcz przeciwnie! Chodzi o region mocno uprzemysłowiony, gęsto zaludniony, gdzie nie ma różnic między stopą życiową w aglomeracjach miejskich i na wsiach. Pielęgnowana tu nadal tzw. tradycyjna kultura ludowa przeplata się z popkulturą lub $\mathrm{z}$ ambitniejszą kulturą narodu czeskiego, względnie polskiego. 


\section{BIBLIOGRAFIA}

BĚLIČ Jaromír, 1955, Sedm kapitol o češtině (Přrispěvky k problematice národního jazyka), Státní pedagogickí nakladatelství, Praha.

BĚLč Jaromír, 1972, Nástin české dialektologie, Státní pedagogické nakladatelství, Praha.

Bogocz Irena, 2017a, Zachodniocieszyńskie stownictwo gwarowe - próba ujęcia tematu, „Poradnik Językowy”, z. 4, s. 21-36.

Bogocz Irena, 2017b, Východolašská nářeči versus gwara zachodniocieszyńska, czyli dialektologiczna wojna o Zaolzie, „LingVaria”, R. XII, t. 2(24), s. 227-244.

Bogoczová Irena, 2015, Nový slovanský pidžin na česko-polské hranici? Několik př́kladů mluvy na českém Těšinsku, „Slavia”, R. 84, nr 4, s. 441-455.

Bogoczová Irena, 2017, Szkice z dialektologii języka czeskiego. 3. Czeska dialektologia od połowy XX w. i jej aktualne zadania, „Bohemistyka”, nr 2, s. 144-162.

BogoczovÁ Irena, BortLICzeK Małgorzata, 2014, 2017, Jazyk přihraničního mikrosvěta (běžná mluva Těšiňanů v ČR) // Język przygranicznego mikroświata (mowa potoczna mieszkańców Zaolzia), Ostravská univerzita, Ostrava.

Bogoczová Irena, Bortliczek Małgorzata, 2016, Potoczny język Polaków na Zaolziu dziś, w: K. Czajkowski, A. Zářický, red., Śladami Polaków na czeskim/ austriackim Ślasku // Stopami Poláki̊ v českém/rakouském Slezsku, Fundacja „Silva Rerum Polonarum”, Częstochowa, s. 287-305.

BurszTa Wojciech Józef, JAskuŁowski Krzysztof, NowaK Joanna, red., 2005, Naród-Tożsamość - Kultura. Między koniecznościa a wyborem, Slawistyczny Ośrodek Wydawniczy, Warszawa.

Damrosz Jerzy, 1999, Wyznaczniki lokalno-regionalne i etniczne $w$ badaniach zróżnicowania kultury nowoczesnych społeczeństw. Próba systematyki pojęć i problemów, w: I. Bukowska-Floreńska, red., Studia etnologiczne i antropologiczne II: Kultury regionalne i pogranicza kulturowe a świadomość etniczna, Wydawnictwo Uniwersytetu Śląskiego, Katowice, s. 23-32.

HavráNEK Bohuslav, 1934, Nářčć česká, w: Československá vlastivěda III (Jazyk), Sfinx, Praha, s. 84-219.

KADŁUBIEC Daniel Karol, 1994, Cieszyńsko-zaolziańska polszczyzna, Wojewódzka Biblioteka Publiczna w Katowicach, Katowice.

KelLner Adolf, 1946, 1947, Východolašská nářeči I, II, Dialektologická komise při Matici moravské, Brno. 
Laвocha Janina, 1997, Polsko-czeskie pogranicze na Śląsku Cieszyńskim. Zagadnienia językowe, Księgarnia Akademicka, Kraków.

Lipińska Ewa, 2015, Dwujęzyczność kognitywna, „LingVaria” R. X, t. 2, s. 55-68. MiszTal Bronisław, 2005, Tożsamość jako pojęcie i zjawisko społeczne $w$ zderzeniu z procesami globalizacji, w: E. Budakowska, red., Tożsamość bez granic. Współczesne wyzwania, Wydawnictwa Uniwersytetu Warszawskiego, Warszawa, s. 21-32.

NowOwIEJSKi Bronisław, 2010, O przyszłości polskich gwar ludowych, w: A. Skudrzyk, E. Rudnicka-Fira, red., Dialektologia. Materiaty pomocnicze. Konteksty socjolingwistyczne, Wydawnictwo Uniwersytetu Śląskiego, Katowice, s. $120-125$.

\section{Irena Bogoczová}

\section{MOWA POLAKÓW NA ZAOLZIU (W KONTEKŚCIE JĘZYKÓW OGÓLNONARODOWYCH I ICH ODMIAN)}

\section{Streszczenie}

Artykuł dotyczy sytuacji językowej na Śląsku Cieszyńskim w Republice Czeskiej, który zamieszkuje m.in. polska mniejszość narodowa. W pierwszej kolejności zostały podane i wyjaśnione podstawowe pojęcia odnoszące się do omawianego regionu i opisane wydarzenia historyczne, które doprowadziły do obecnej sytuacji językowej. Następnie przytoczono cechy typowego członka polskiej mniejszości na Śląsku w Republice Czeskiej. W dalszej kolejności poświęcono uwagę językom i ich odmianom, które kształtowały lokalną mowę potoczną, szczególnie zaś samej mowie „po naszymu", przedstawionej we fragmentach autentycznych tekstów. W artykule zawarto również informacje o tym, jak przebiegały spory o afiliację gwary zachodniocieszyńskiej do czeskiego lub polskiego języka etnicznego.

\section{THE SPEECH OF POLES IN THE ZAOLZIE REGION (IN THE CONTEXT OF ETHNIC LANGUAGES AND THEIR VARIETIES)}

\section{Summary}

This article deals with the language situation in the Czech part of Cieszyn in Silesia, where, among others, members of a Polish national minority live. First, the author introduces and explains basic notions concerning the region and offers a brief description of the historical development that has led to its present state. She presents the basic properties of a typical member of the Polish minority in the Czech part of Silesia. Subsequently, the author devotes attention to the languages and their varieties which have shaped the local common language, especially the speech itself, which is presented in the form of extracts from authentic texts. The third part of the article contains information about how disputes about the affiliation of the West Cieszyn dialect to the Czech or Polish ethnic language took place. 